\title{
PEMBELAJARAN PRAKTIKUM DENGAN MODUL BERBASIS SCIENCE, TECHNOLOGY, ENGINEERING AND MATHEMATICS (STEM) UNTUK MENINGKATKAN HASIL BELAJAR SISWA PADA KOMPETENSI DASAR MELAKUKAN DASAR PENGAWETAN
}

\author{
Learning Practicum With Modules Based on Science, Technology, Engineering and Mathematics \\ (STEM) to Increase Student Learning Results on The Basic Competency \\ to Do The Preservation
}

\author{
Eulis Safitri $^{1}$, Sri Handayani ${ }^{2}$, Siti Mujdalipah ${ }^{3}$ \\ 1,2, 3 Program Studi Pendidikan Teknologi Agroindustri, \\ Fakultas Pendidikan Teknologi dan Kejuruan, Universitas Pendidikan Indonesia \\ *Korespondensi: eulissafitri@gmail.com
}

\begin{abstract}
ABSTRAK
Penelitian ini bertujuan mengetahui hasil belajar siswa yang menggunakan modul berbasis STEM, mengetahui hasil belajar siswa yang menggunakan modul Non-STEM dan mengetahui perbedaan hasil belajar siswa yang menggunakan modul berbasis STEM dengan siswa yang menggunakan modul Non-STEM. Hal tersebut untuk mengetahui hasil belajar dalam ranah kognitif dan ranah psikomotorik. Metode penelitian yang digunakan adalah Quasy Eksperiment dengan desain pretest-posttest yang dilakukan dalam 4 kali pertemuan dengan 2 kegiatan praktikum yaitu praktikum permen karamel dan praktikum telur asin. Subyek penelitian ini adalah siswa SMKN 4 Garut sebanyak 66 orang, yang terdiri dari dua kelas. Kelas X TPHP A sebagai kelas kontrol yang menggunakan modul Non-STEM. Kelas X TPHP B sebagai kelas eksperimen yang menggunakan modul berbasis STEM. Setelah melaksanakan praktikum, penggunaan modul berbasis STEM dapat meningkatkan hasil belajar siswa pada ranah kognitif dan psikomotorik dibandingkan penggunaan modul Non-STEM. Aspek kognitif pada kelas menggunakan modul berbasis STEM memiliki nilai $\mathrm{N}$-gain lebih tinggi dibandingkan kelas dengan modul Non-STEM. Ketuntasan belajar pada kelas yang menggunakan modul berbasis STEM sebesar $85 \%$ pada praktikum permen karamel dan $76 \%$ pada praktikum telur asin, sedangkan pada kelas yang menggunakan modul Non-STEM sebesar $70 \%$ pada praktikum permen karamel dan $61 \%$ pada praktikum telur asin. Pada aspek psikomotor ditemukan terdapat beberapa kelompok siswa yang belum mencapai nilai optimum pada beberapa indikator khususnya untuk kelas kontrol. Aspek psikomotorik kelas menggunakan modul berbasis STEM pada aspek persiapan kerja, proses kerja, hasil kerja, kemasan dan waktu memiliki nilai yang lebih tinggi dibandingkan kelas dengan modul Non-STEM yaitu kategori amat baik. Kata kunci: modul praktikum berbasis STEM, hasil belajar
\end{abstract}

\begin{abstract}
This study aims to find out the learning outcomes of students who use STEM-based module, knowing the learning outcomes of student who use the Non-STEM module, and knowing the differences in student learning outcomes using STEM-based module with student who use the Non-STEM module. Determine learning outcomes in the term of cognitive and psychomotor domains. The research method used was Quasy Experiment with pretest-posttest design which was done in 4 face-to-face class with two practicum activities. The practicum are caramel candy and salted egg making. The subjects of this study were students of SMKN 4 Garut totally 66 students, consisting of two classes. Class X TPHP A as a control class whic is using the Non-STEM module. Class X TPHP B as an experimental class which is using STEM-based module. After finishing out the lab, activities of STEM-based modules can improve student learning outcomes in the cognitive and psychomotor areas compared to the use of Non-STEM modules. The cognitive aspects of a class using STEM-based modules have a higher $\mathrm{N}$-gain value than a class with a Non-STEM module. The learning completeness using STEM-based modules is $85 \%$. On which caramel candy practicum and $76 \%$ on salted egg. Practicum mean while in the class is using the Non-STEM module is $70 \%$ on caramel candy and $61 \%$ on salted egg. Further more in psychomotor aspect, there are found some groups of students practicum that have not reached the practicum optimum value in some indicators, especially for the control class. Psychomotor aspects of the class using STEM-based modules on aspects of work preparation, work processes, work result, packaging, and time a higher value than the class using the Non-STEM module which is a very good category.
\end{abstract}

Keywords: STEM-based practicum modules, learning outcomes 


\section{PENDAHULUAN}

Kurikulum 2013 di SMKN 4 Garut menuntut siswa lebih aktif dalam mencari informasi dari berbagai sumber yang bertujuan melatih dan mengembangkan keterampilan. Salah satu cara yang dapat dilakukan yaitu melalui kegiatan praktikum. Kegiatan praktikum menjadikan siswa memiliki keahlian dalam bidang pengolahan hasil pertanian. Sama halnya dengan pernyataan menurut Rahmat \& Syahni yang dikutip Risma (2012) bahwa lulusan SMK dituntut memiliki keahlian di bidang tertentu dan dapat mengisi lowongan kerja yang ada sehingga pembelajaran di SMK sebesar $70 \%$ diisi dengan praktek dan hanya 30\% teori. Pentingnya kegiatan praktikum di SMKN 4 Garut dikarenakan siswa harus mempunyai kompetensi yang harus dikuasai dengan kebutuhan dunia industri dan dunia usaha. Salah satu program keahlian yang ada di SMKN 4 Garut yang mengolah hasil pertanian adalah Agribisnis Pengolahan Hasil Pertanian yang lulusannya ditujukan untuk kebutuhan dunia industri dan dunia usaha pada bidang pengolahan hasil pertanian. Salah satu kompetensi dasar pada program keahlian APHP yang harus dimiliki oleh siswa adalah menerapkan dan mengolah hasil pertanian. Kompetensi dasar tersebut tertuang dalam tujuan pembelajaran mata pelajaran dasar proses pengolahan hasil pertanian dan perikanan, yaitu melakukan dasar pengawetan.

Oleh karena itu, pembelajaran ini harus direncanakan dan dilaksanakan dengan baik demi tercapainya tujuan pembelajaran dan mampu mengarahkan siswa untuk mampu mencapai kompetensi dasar yang ditentukan. Berdasarkan observasi awal dan pengalaman PPL (Program Pengalaman Lapangan) di SMK Negeri 4 Garut program keahlian Agribisnis Pengolahan Hasil Pertanian (APHP), guru produktif berpendapat bahwa masih banyak siswa yang bertanya mengenai prosedur kerja ketika melakukan kegiatan praktikum, meskipun telah disampaikan sebelumnya. Sementara itu, masalah yang dihadapi siswa saat kegiatan praktikum adalah tidak dibekali dengan panduan atau sumber belajar seperti modul. Kondisi ini akan mempengaruhi kualitas pembelajaran dan keberhasilan belajar yang hendak dicapai. Citrawathi (2015), mendapatkan hasil belajar siswa dengan menggunakan bantuan modul pada siklus tiga sebesar $93,02 \%$ atau sangat baik, tujuan penelitian ini adalah mengetahui hasil belajar siswa menggunakan modul berbasis STEM, mengetahui hasil belajar siswa menggunakan modul Non-STEM, mengetahui apakah terdapat perbedaan hasil belajar siswa menggunakan modul berbasis STEM dengan siswa menggunakan modul Non-STEM.

\section{METODE}

Metode penelitian yang digunakan adalah nonequivalent control group. Populasi yang digunakan pada penelitisn ini adalah siswa kelas X Program Studi Teknologi Hasil Pertanian di SMKN 4 Garut. Penentuan sampel menggunakan teknik purposive sampling sehingga sampel dalam penelitian ini adalah siswa kelas X TPHP A yang berjumlah 33 siswa dan X TPHP B yang berjumlah 33 siswa. Data yang terkumpul dianalisis menggunakan analisis penilaiain kognitif (menghitung nilai rata-rata dan menghitung, analisis penilaiain psikomotorik dan uji hipotesis. Analisis data sebagai berikut:

1. Analisis Penilaian Kognitif

a. Menghitung Nilai Rata-rata

Nilai siswa diperoleh dengan menggunakan rumus (Sukardi, 2008)

$$
\text { Nilai }=\frac{\text { Skor } \text { yang diperoleh siswa }}{\text { Skor maksimum }} \times 100
$$

Rata-rata nilai siswa diperoleh dengan menggunakan rumus:

$$
\bar{x}=\frac{\text { Jumlah nilai }}{\text { Banyaknya data }}
$$


Rata-rata nilai siswa yang telah diperoleh kemudian dikonversikan pada Tabel 1

Tabel 1. Katagori Tafsiran Rata-Rata Hasil Belajar Siswa Terhadap Materi

\begin{tabular}{cc}
\hline Nilai rata-rata & Keterangan \\
\hline $40-55$ & Sangat rendah \\
$56-65$ & Rendah \\
$66-75$ & Sedang \\
$76-85$ & Tinggi \\
$86-100$ & Tinggi sekali \\
\hline
\end{tabular}

Sumber : (Sukardi, 2008)

Untuk efektifitas peningkatan hasil belajar dapat diketahui dengan menggunakan teknik Normalized Gain, yaitu dengan rumus:

$$
N \text {-Gain }=\frac{\text { Skor post test }- \text { Skor pre test }}{\text { Skor Maksimum }- \text { Skor pre test }}
$$

Skala nilai yang digunakan pada data $\mathrm{N}$-Gain terdapat pada table 2 berikut:

Tabel 2. Kriteria Normalized Gain

\begin{tabular}{cc}
\hline Skor $N$-Gain & Kriteria $N$-Gain \\
\hline $0,70<N$-Gain & Tinggi \\
$0,30<N$-Gain $\leq 0,70$ & Sedang \\
$N$-Gain $\leq 0,30$ & Rendah \\
\hline Sumber : $($ Hake, 1998)
\end{tabular}

b. Menghitung Presentase Jumlah Siswa Tuntas

Untuk menghitung presentase jumlah siswa yang tuntas atau telah memenuhi nilai KKM pada Kompetensi Dasar Pengawetan yaitu 75, diformulasikan sebagai berikut:

$$
\begin{aligned}
& \text { Presentase Siswa Tuntas }=\frac{\text { Siswa tuntas }(\text { memenuhi Nilai KKM })}{\text { JumlahSeluruh Siswa }} \times 100 \% \\
& \text { Sumber : (Prihardina, 2012) }
\end{aligned}
$$

2. Analisis Penilaiain Psikomotorik

Skala penilaian terentang dari tidak sempurna sampai sangat sempurna, misalnya pada Tabel 3 sebagai berikut: 
Tabel 3. Penilaian Psikomotorik

\begin{tabular}{cc}
\hline Gradasi Mutu & Kriteria \\
\hline 4 & Sangat baik \\
3 & Baik \\
2 & Cukup \\
1 & Kurang baik \\
\hline
\end{tabular}

Nilai akhir untuk ranah keterampilan diambil dari nilai optimal (nilai tertinggi yang dicapai). Indikator pada setiap aspek penilaian praktikum dihitung menggunakan rumus sebagai berikut:

$$
P i=\frac{n i}{N}
$$

Keterangan:

$$
\begin{aligned}
& \mathrm{Pi}=\text { persentase siswa dalam setiap tingkat kemampuan } \\
& \mathrm{ni}=\text { banyaknya siswa dalam setiap kemampuan } \\
& \mathrm{N}=\text { banyaknya seluruh siswa } \\
& \mathrm{i}=\text { nilai siswa }
\end{aligned}
$$

3. Uji Hipotesis

a. Uji normalitas

Nilai signifikansi atau probabilitas $<0,05$, maka data terdistribusi secara tidak normal.

Nilai signifikansi atau probabilitas $>0,05$, maka data terdistribusi secara normal.

b. Uji homogenitas

Nilai Sig. atau signifikansi atau nilai probabilitas $>0,05$ maka, data bervarian sama atau homogen.

c. Hipotesis

Pengambilan keputusan dilakukan dengan cara membandingkan nilai $t_{\text {hitung }}$ dengan $t_{\text {tabel }}$ dengan ketentuan:

Jika $\pm \mathrm{t}_{\text {hitung }}<\mathrm{t}_{\text {tabel }}$, maka $\mathrm{H}_{0}$ diterima dan $\mathrm{H}_{1}$ ditolak

Jika $\pm \mathrm{t}_{\text {hitung }}>\mathrm{t}_{\text {tabel }}$, maka $\mathrm{H}_{0}$ ditolak dan $\mathrm{H}_{1}$ diterima

Selain itu, pengambilan keputusan juga dapat dilihat dari taraf sinifikan $\mathrm{p}$ (sig 2-tailed). Jika $p>0,05$ maka $\mathrm{H}_{0}$ diterima dan jika $p<0,05$ maka $\mathrm{H}_{0}$ ditolak (Budi, Triton, 2006).

Adapun hipotesis dalam penelitian ini dengan rincian sebagai berikut:

Ha: $\mu 1 \neq \mu 2$ : terdapat perbedaan hasil belajar yang positif dan signifikan antara kelas yang menggunakan modul berbasis STEM dengan kelas yang menggunakan modul NonSTEM pada kompetensi dasar melakukan dasar pengawetan di SMKN 4 Garut.

H0: $\mu 1=\mu 2$ : tidak terdapat perbedaan hasil belajar yang positif dan signifikan antara kelas yang menggunakan modul berbasis STEM dengan kelas yang menggunakan modul NonSTEM pada kompetensi dasar melakukan dasar pengawetan di SMKN 4 Garut. 


\section{HASIL DAN PEMBAHASAN}

\section{Penilaian Kognitif}

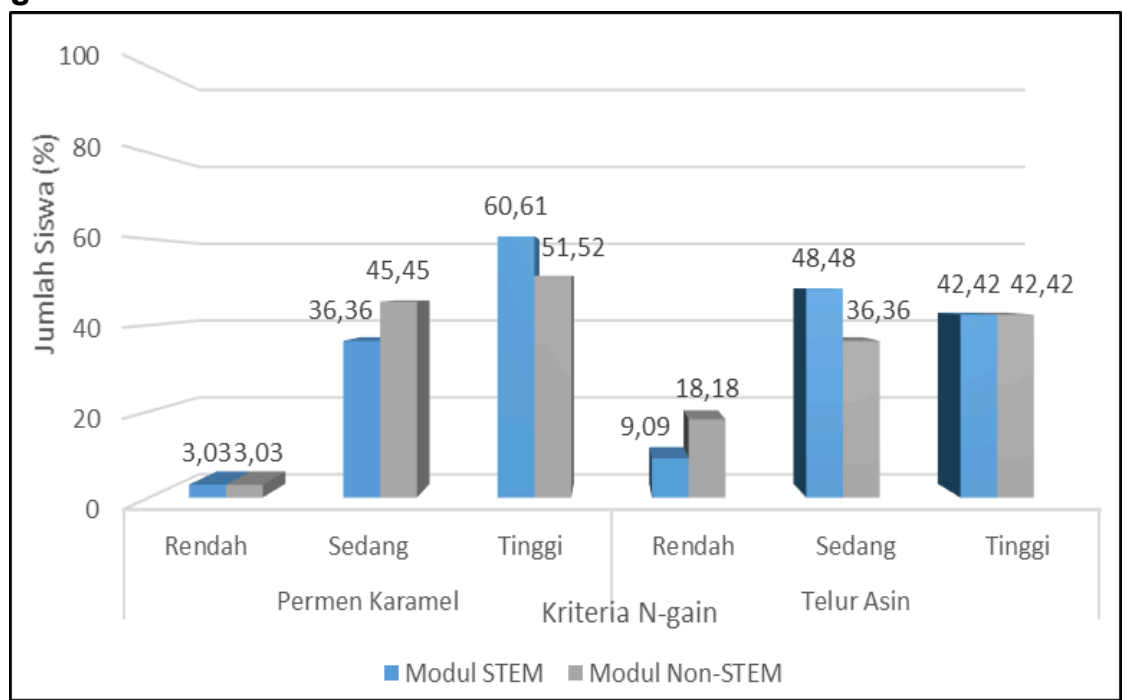

Gambar 1. Peningkatan Hasil Belajar Siswa pada Ranah Kognitif

Hasil nilai rata-rata siswa pada kedua kegiatan praktikum dari kelas eksperimen yang menggunakan modul berbasis STEM peningkatannya lebih besar karena pada pelaksanaan praktikum menuntut siswa mengembangkan praktikum dengan mempertimbangkan semua aspek, baik aspek dari sisi science, technology, engeenering, and mathematic yang beradapadabimbingan guru. Kemudian adanya pemberian stimulus yang lebih dibandingkan kelas kontrol, kelas eksperimen diberikan beberapa formulasi yang menuntut siswa berpikir kreatif dalam menyelesaikan setiap langkah kegiatan praktikum. Sedangkan kelas kontrol yang menggunakan modul Non-STEM yaitu siswa hanya difokuskan pada langkah kerja yang ada pada modul tanpa arahan untuk mempertimbangkan sudut pandang lain.Setelah menghitung nilai $\mathrm{N}$-gain, kemudian menghitung persentase jumlah peserta didik yang tuntas atau telah memenuhi nilai KKM setelah (post-test) proses kegiatan praktikum pada kompetensi dasar melakukan dasar pengawetan yaitu 75. Adapun persentase ketuntasan (post-test) kelas kontrol dan kelas eksperimen dapat dilihat pada gambar Gambar 2.

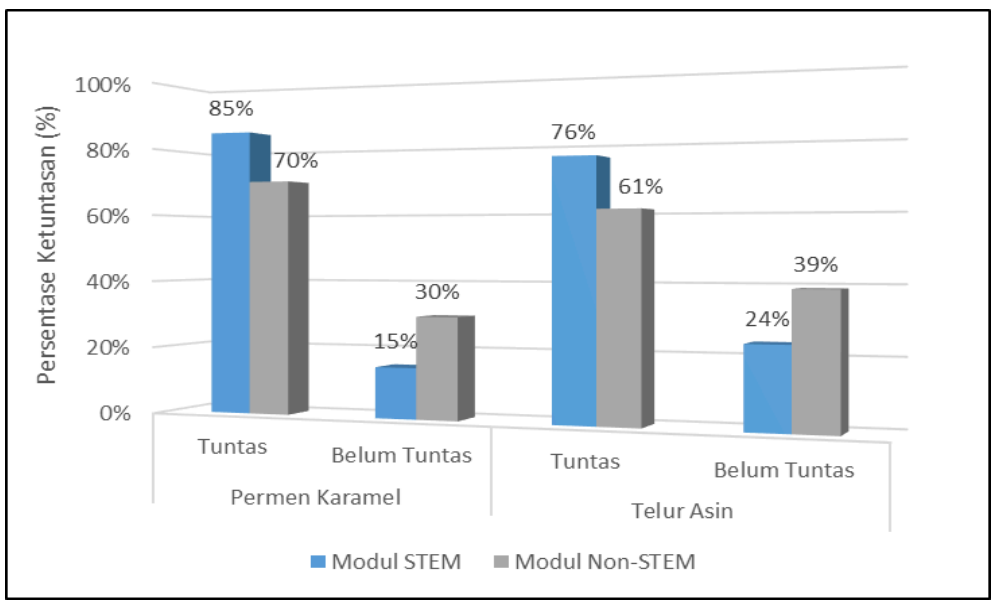

Gambar 2. Persentase Ketuntasan Belajar Siswa pada Ranah Kognitif

Berdasarkan pada Gambar 2. Persentase ketuntasan belajar siswa pada kedua kegiatan praktikum kelas eksperimen dengan menggunakan modul berbasis STEM memiliki nilai yang lebih 
besar yaitu pada praktikum permen karamel sebesar $85 \%$ dan praktikum telur asin sebesar $76 \%$. Hal ini pun dapat terjadi karena menurut Yuliati dkk (2011) bawah beberapa kegiatan seperti diskusi dan pembuatan proyek dapat meningkatkan hasil belajar siswa.

\section{Penilaian Psikomotorik}

Ketercapaian hasil belajar siswa pada ranah psikomotorik ini dinilai oleh guru dengan indikator penilaian praktikum, yaitu: persiapan alat, persiapan bahan, sistematika kerja, hasil produk, kemasan produk, dan waktu penyelesaian. Penilaian hasil belajar siswa pada ranah psikomotor dilakukan berdasarkan nilai optimum atau nilai tertinggi yang dicapai siswa terhadap keenam indikator penilaian tersebut. Berdasarkan data yang diperoleh perbandingan penilaian psikomotorik kemudian diinterprestasikan ke dalam bentuk persentase ketuntasan siswa. Persentase ketuntasan siswa dalam penilaian psikomotorik disajikan pada Gambar 3 dan 4.

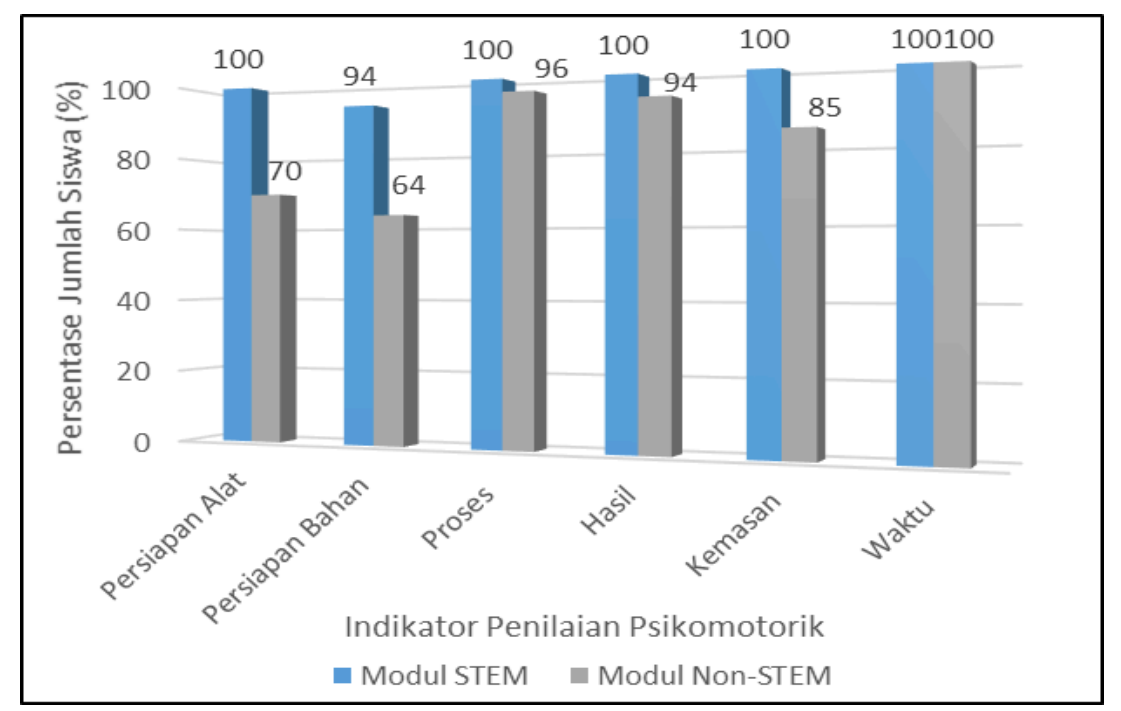

Gambar 3. Ketercapaian Penialaian Ranah Psikomotrik Praktikum Permen Karamel

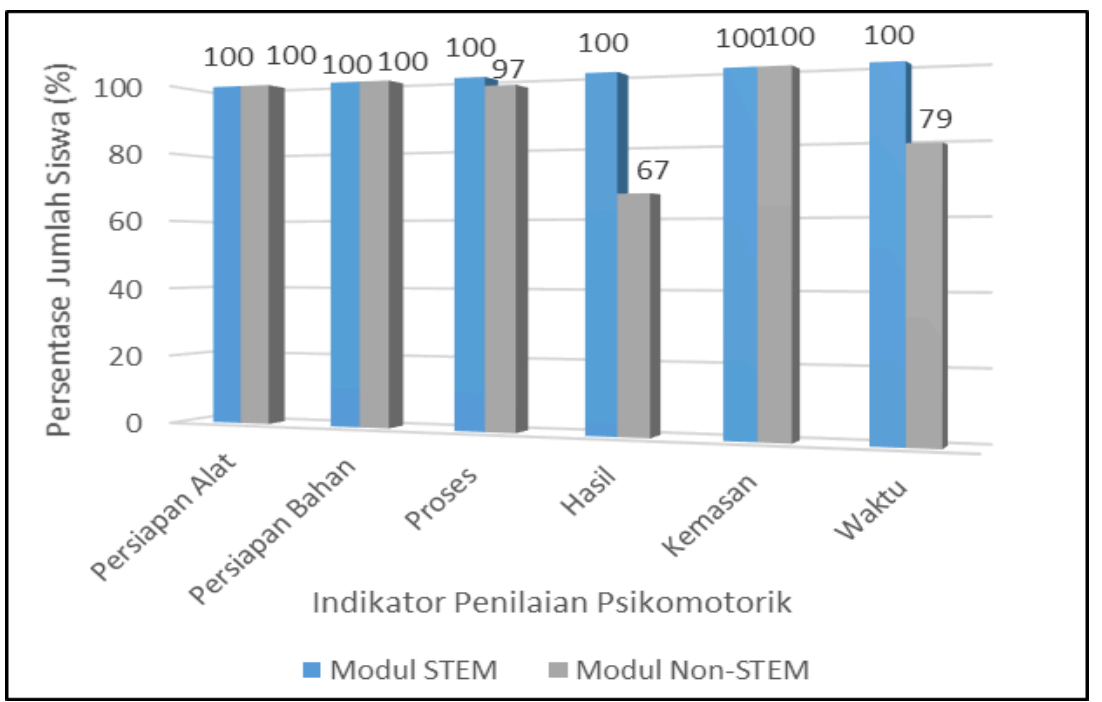

Gambar 4. Ketercapaian Penialaian Ranah Psikomotrik Praktikum Telur Asin

Berdasarkan paparan di atas, hasil belajar siswa pada ranah psikomorik menyatakan bahwa terdapat beberapa kelompok yang belum mencapai nilai optimum pada beberapa indikator penilaian khususnya untuk kelas kontrol. Sedangkan hasil belajar pada ranah psikomotorik ini untuk kelas eksperimen memiliki nilai lebih tinggi sehingga diperoleh nilai yang amat baik dengan 
nilai pada rentang 3-4. Dengan demikian, modul berbasis STEM dapat meningkatkan aspek psikomotorik siswa pada kompetensi dasar melakukan dasar pengawetan.

\section{Hasil Hipotesis}

Berdasarkan hasil uji Independent-Sample $T$ Test, diketahui pada praktikum permen karamel adalah $\mathrm{t}_{\text {hitung }}<\mathrm{t}_{\text {tabel }}$ yaitu $1,63<1,99$, maka $\mathrm{H}_{0}$ diterima dan $\mathrm{H}_{1}$ ditolak. Sedangkan pada praktikum telur asin adalah $t_{\text {hitung }}>t_{\text {tabel }}$ yaitu $7,88>1,99$, maka $\mathrm{H}_{0}$ ditolak dan $\mathrm{H}_{1}$ diterima. Oleh karena itu, hipotesis pada praktikum permen karamel dinyatakan bahwa tidak terdapat perbedaan hasil belajar yang positif dan signifikan antara kelas yang menggunakan modul berbasis STEM dengan kelas yang menggunakan modul Non-STEM pada kompetensi dasar melakukan dasar pengawetan di SMKN 4 Garut. Sedangkan hipotesis pada praktikum telur asin dinyatakan bahwa terdapat perbedaan hasil belajar yang positif dan signifikan antara kelas yang menggunakan modul berbasis STEM dengan kelas yang menggunakan modul Non-STEM pada kompetensi dasar melakukan dasar pengawetan di SMKN 4 Garut.

\section{KESIMPULAN}

1. Kegiatan praktikum yang menggunakan modul berbasis STEM dapat meningkatkan hasil belajar siswa pada aspek kognitif yang dilihat dari ketuntasan belajar pada praktikum permen karamel sebesar $76 \%$ dan pada praktikum telur asin sebesar $85 \%$. Dengan nilai $\mathrm{N}$-gain yaitu pada praktikum pembuatan permen karamel sebesar 0,76 dan praktikum pembuatan telur asin sebesar 0,68. Kegiatan praktikum yang menggunakan modul berbasis STEM dapat meningkatkan hasil belajar pada aspek psikomotor siswa yang dilihat dari nilai keterampilan saat melakukan praktikum dengan cara bereskperimen pada praktikum pembuatan permen karamel dengan menggunakan berbagai konsentrasi gula dan pada praktikum pembuatan telur asin menggunakan berbagai macam metode atau teknik membuat telur asin yang berkualitas.

2. Kegiatan praktikum yang menggunakan modul Non-STEM untuk hasil belajar pada aspek kognitif siswa yang dilihat dari ketuntasan belajar pada praktikum permen karamel sebesar $61 \%$ dan pada praktikum telur asin sebesar $70 \%$. Hal ini menunjukan bahwa pada aspek kognitif kelas yang menggunakan modul berbasis STEM untuk ketuntasan belajar jauh lebih tinggi. Dengan nilai $\mathrm{N}$-gain pada praktikum pembuatan permen karamel sebesar 0,71 dan praktikum pembuatan telur asin sebesar 0,64 .

3. Hasil uji Independent-Sample $T$ Test, diketahui pada praktikum permen karamel adalah $\mathrm{t}_{\text {hitung }}<$ $t_{\text {tabel }}$ yaitu $1,63<1,99$, maka $\mathrm{H}_{0}$ diterima dan $\mathrm{H}_{1}$ ditolak. Sedangkan pada praktikum telur asin adalah $t_{\text {hitung }}>t_{\text {tabel }}$ yaitu $7,88>1,99$, maka $\mathrm{H}_{0}$ ditolak dan $\mathrm{H}_{1}$ diterima. Oleh karena itu, hipotesis pada praktikum permen karamel dinyatakan bahwa tidak terdapat perbedaan hasil belajar yang positif dan signifikan antara kelas yang menggunakan modul berbasis STEM dengan kelas yang menggunakan modul Non-STEM pada kompetensi dasar melakukan dasar pengawetan di SMKN 4 Garut. Sedangkan hipotesis pada praktikum telur asin dinyatakan bahwa terdapat perbedaan hasil belajar yang positif dan signifikan antara kelas yang menggunakan modul berbasis STEM dengan kelas yang menggunakan modul Non-STEM pada kompetensi dasar melakukan dasar pengawetan di SMKN 4 Garut. Kemudian untuk nilai rata-rata praktikum permen karamel pada kelas yang menggunakan modul STEM sebesar 86,88 dan pada kelas yang menggunakan modul Non-STEM sebesar 82,00 . Sedangkan, nilai rata-rata praktikum telur asin pada kelas yang menggunakan modul STEM sebesar 84,42 dan pada kelas yang menggunakan modul Non-STEM sebesar 79,64 . Nilai rata-rata tersebut menunjukan bahwa hasil belajar siswa yang menggunakan modul praktikum berbasis STEM memiliki nilai yang lebih tinggi daripada siswa yang menggunakan modul Non-STEM . 


\section{DAFTAR PUSTAKA}

Budi, Trition Prawira. (2006). SPSS 13.0 Terapan: Riset Statistik Parametrik. Yogyakarta: CV Andi Offset.

Citrawathi, D.M. (2015). Pengembangan Pembelajaran Biologi dengan Menggunakan Modul Berorientasi Siklus Belajar dan Pengaruhnya Terhadap Hasil Belajar Siswa Di SMA. .Jurnal Pendidikan dan Pengajaran IKIP Negeri Singaraja, 3, 534-551.

Prihardina, M. (2012). Penerapan Model Pembelajaran Learning Cycle untuk Meningkatkan Hasil Belajar Siswa Kelas V Pada Pembelajaran IPA Materi Pokok Sifat-sifat Cahaya (Skripsi). Pada Program Pendidikan Guru Sekolah Dasar FIP UPI. Bandung: Tidak Diterbitkan.

Sukardi. (2008). Metodologi Penelitian Pendidikan, Kompetensi dan Praktiknya. Jakarta: PT. Bumi Aksara.

Yuliati, D.I., D. Yulianti, \& S. Khanafiyah. (2011). Pembelajaran Fisika Berbasis Hands on Activities untuk Menumbuhkan Kemampuan Berpikir Kritis dan Meningkatkan Hasil Belajar Siswa SMP. Jurnal Pendidikan Fisika Indonesia, 7, 23-27. Tersedia di https://journal.unnes.ac.id [diakses 19-5-2018]. (1), 86-94. 